\author{
Goran Ocokoljić \\ $\mathrm{Dr}$, Chief of Experimental Aerodynamics \\ Military Technical Institute (VTI) \\ Belgrade \\ Dijana Damljanović \\ Dr, Lead Research Engineer \\ Military Technical Institute (VTI) \\ Belgrade \\ Đorđe Vuković \\ Lead Research Engineer \\ Military Technical Institute (VTI) \\ Belgrade \\ Boško Rašuo \\ Professor \\ University of Belgrade \\ Faculty of Mechanical Engineering \\ Aeronautical Department
}

\section{Contemporary Frame of Measurement and Assessment of Wind-Tunnel Flow Quality in a Low-Speed Facility}

The requirements for the accuracy of measurements in a wind tunnel test become more and more severe while the complexity of the test increases. In an environment of reduced time available for wind tunnel test and increasing test costs, it is important that the accurate calibrations and verifications of all components of the measurement chain in a wind tunnel facility are established, maintained and statistically controlled through prolonged periods of time. The paper presents the efforts undertaken to establish and maintain a system of control of the quality of measurements in the T-35 $4.4 \mathrm{~m} \times 3.2 \mathrm{~m}$ low-speed wind tunnel of the Military Technical Institute in Belgrade. The assurance of the quality of measurement in this facility is based on ensuring the quality of three main constituents: the calibration of the test section of the wind tunnel, the calibration of the instrumentation used, and the periodic tests of the standard wind tunnel models. Sample results from relevant wind tunnel calibration tests are presented and compared with the results from other facilities. The tests confirmed a good overall quality of the facility, and that the achieved quality level has to be maintained, periodically checked and systematically documented.

Keywords: Wind-tunnel flow quality; Low-speed wind tunnel; Standard calibration models; AGARD-B; ONERA M4.

\section{INTRODUCTION}

Wind-tunnel testing is an essential part of the design and development of any aircraft. The usual practice in a prediction of the aerodynamic behaviour and characteristics of a future flight object is to perform windtunnel tests of relatively small-scale models. To ensure a meaningful interpretation of wind-tunnel data, influences affecting the results must be understood and corrected; the corrected data should be comparable to data from different tunnels or to a free-air situation, [1]-[9]. Additionally, it is desirable that more or less standard calibration and test procedures are adopted in order to make data from different tunnels as nearly comparable as possible. As the requirements for the accuracy of measurements in a wind tunnel test become more and more severe while the complexity of the test increase, and in an environment of reduced time available for the wind tunnel test and increasing test costs, it is important that accurate calibrations and verifications of all components of the measurement chain in a wind tunnel facility are established and, even more important, maintained and statistically controlled [10] through prolonged periods of time.

Before the wind-tunnel results of a test model can be used to predict the aerodynamic characteristics of a future flight object, the effects of the model-support system and the non-uniform air-flow conditions must be determined

Received: November 2017, Accepted: March 2018

Correspondence to: Prof. Boško Rašuo, University of Belgrade, Faculty of Mechanical Engineering, Kraljice Marije 16, 11120 Belgrade, Serbia

E-mail: brasuo@mas.bg.ac.rs

doi:10.5937/fmet18044290

(C) Faculty of Mechanical Engineering, Belgrade. All rights reserved and applied to the measured aerodynamic characteristics, [11]. Research in the wind-tunnel flow-field quality is a significant part of experimental aerodynamics and includes a number of different methods based on pressure distribution measurements using diverse types of probes and/or scanning devices. These methods enable the determination of velocity and pressure profiles, calculation of the Mach number, examination of boundary layer nature and thickness, etc. Measurements of the Mach number correction and flow angularity in the test section are considered to be the most essential to perform, as they directly influence the calculation of aerodynamic coefficients. The non-uniformities in the flow-field may be thought of as belonging in the three following categories: (1) A change in the average airspeed along the longitudinal axis of the tunnel, (2) A variation in airspeed over a plane perpendicular to the longitudinal axis, (3) A variation in the air-flow angle in the region occupied by the model.

The T-35 wind tunnel of the Military Technical Institute (VTI) in Belgrade is a primary large low-speed experimental aerodynamics facility in Serbia. As a part of the effort to ensure and maintain the quality of measurement and wind tunnel's competitiveness with other wind tunnels, it is very important to certify the overall reliability of the T-35 by a thorough understanding of the flow conditions in the test section and by comparing models test data with the data acquired in other reference wind-tunnels. It is also important to confirm data consistency between the different-speed-range wind tunnels in VTI.

The assurance of the quality of measurement in the T35 wind tunnel is based on ensuring the quality of three 
main constituents: the calibration of the test section of the wind tunnel, the calibration of the instrumentation used, and the periodic tests of the standard wind tunnel models.

Recalibration of all the wind tunnel instrumentation is a periodic task, repeated at intervals usually ranging from three months to one year. An important drawback in this respect is the lack of universally agreed-upon metrological treatment of some complex sensors like the multicomponent internal wind tunnel balances, which are perhaps the most important tool of experimental aerodynamics and for which the calibration procedures [7] and even the definitions of the term "accuracy" significantly differ from laboratory to laboratory. Regarding the recalibration of the wind tunnel instrumentation, one should also have in mind the emergence of new generations of sensors with muchimproved stability and accuracy, e.g. the digital-output pressure sensors offering for routine applications the accuracies that, twenty years ago, were reserved for the pressure standards in calibration laboratories.

On the other hand, the calibration of the test section of a wind tunnel was, in the past, usually performed once (e.g. during the commissioning of a facility) or after significant modifications to a wind tunnel structure. There are strong indications and recommendations [6], however, that periodical recalibrations of the wind tunnels are essential in order to account for aging of the structures, e.g. the deterioration of components in the electronic systems, the deterioration of various actuators and positioning mechanisms, the accumulation of dust on the turbulence screens in the settling chambers or the deformations of the wind tunnel structures because of the subsidence of foundations.

Periodic tests (e.g. biannual) of standard models are perhaps the most informative component of the monitoring and maintenance of the quality of a wind tunnel facility, because they verify the complete measurement chain in a wind tunnel, from the tunnel structure to the data reduction software and even the personnel operating the wind tunnel. More specifically, standard wind-tunnel models are used for confirmation of the reliability of the data from a new wind-tunnel by a comparison with the results from other wind-tunnel facilities, providing baselines for the correlation of results from different wind-tunnels, checkouts of data repeatability over time, [10]. Deviations in the results from a test of a standard model are easily spotted and usually easy to trace to their source so that the appropriate actions can be undertaken. Besides, the results from the wind-tunnel tests of standard models are used as test cases for verification of the computational-fluiddynamics (CFD) computer codes, [12][13].

In order to raise validity of experimental results obtained in wind-tunnels, it is necessary to increase a model size. Large scale of the model promotes a more complete geometrical similarity between the model and full-scale vehicle because small details of the model are reproduced. On the other hand, the model has to be built to a size suitable for the size of a specific wind-tunnel test section, in particular taking care that the frontal blockage of the model is kept well below $1 \%$ of the working section area, except for wall-interference research where the models may be larger. Related to this issue, standard models of several sizes are sometimes tested in the same wind tunnel. In order to eliminate the effects of production differences between the models in inter-facility comparisons, sometimes the same physical standard model is tested in several wind-tunnels.

The review of obtained calibration- and standard-model test results with respect to data quality is essentially statistical in nature, the main parameters being the means and the standard deviations of acquired data, in comparison with the results previously obtained in the same facility and in comparison with the similar results from other facilities. From this data, the uncertainty of the test process can be assessed and checked. In the paper, the concepts of the calibration procedures and the configurations of the standard models used in the verifications of the T-35 wind tunnel facility are described, and the sample test results correlated with the results from other wind-tunnels are presented.

\section{THE T-35 WIND-TUNNEL FACILITY}

VTI's T-35 experimental facility (Figure 1) is a large subsonic wind-tunnel of a continual type with interchangeable, $3.2 \mathrm{~m} \times 4.4 \mathrm{~m}$, octagonal test sections (Figure 2), [14]. The wind-tunnel, designed by VTI, has been operating since 1964 and has been modernized two times. Mach number range is up to 0.5. Mach number regulation is achieved by changing fan rotation rate and pitch angle of fan blades. Reynolds number is up to $12 \times 10^{6} 1 / \mathrm{m}$. The value of the total pressure in the test section is up to $120 \mathrm{kPa}$ (1.2 bar) (static pressure is atmospheric) and, theoretically, the duration of a test is unlimited.

Two test sections are available, one with an underfloor external balance and another with a tail sting support on a vertical quadrant. The six-component underfloor balance permits step-by-step movements in yaw and pitch. The tail sting support enables step-by-step and continuous (sweep) rotation of the model in all three axes, i.e. changes of the angles of yaw, pitch and roll.

\section{WIND-TUNNEL MEASUREMENT INSTRUMENTATION}

The flow parameters $\mathrm{M} \infty$ and q $\infty$ are determined on the basis of two measured pressures. In the previous tests, the stagnation pressure in the test section was measured by an absolute pressure transducer pneumatically connected to a Pitot probe in the settling chamber of the wind-tunnel. The measuring range of the transducer was $165 \mathrm{kPa}$. The nonlinearity and hysteresis of this type of transducers was $0.04 \%$ F.S.

The difference between the stagnation and static pressure in the test section was measured by a differential pressure transducer, pneumatically connected to the Pitot probe and to the orifices on the test section sidewall. The measuring range of the transducer was $35 \mathrm{kPa}$, and its nonlinearity and hysteresis were $0.05 \%$ F.S. However, in order to improve the quality of the measurement of basic flow parameters, the previously used pressure transducers are currently being replaced with new ones with digital output, having similar pressure ranges but an improved accuracy of $0.01 \%$ F.S. 

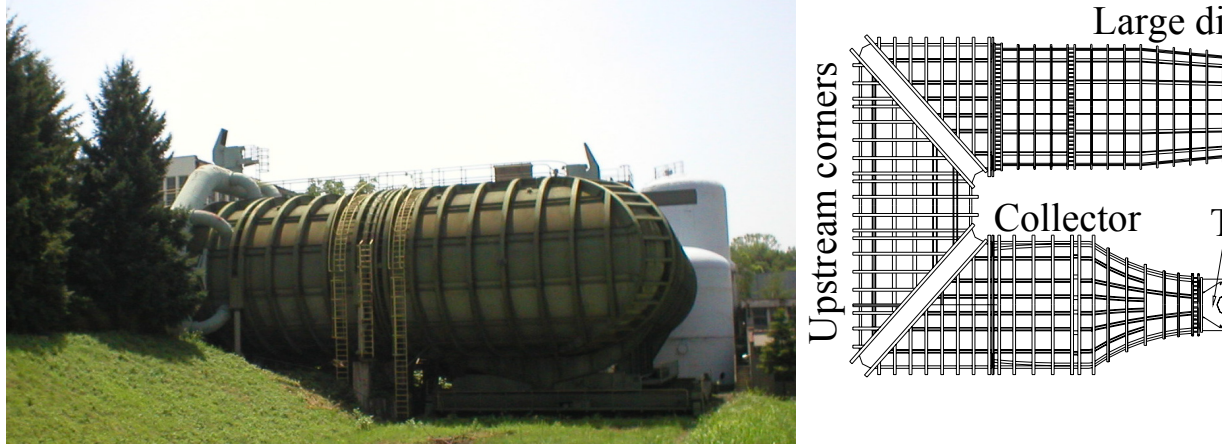

Figure 1. The T-35 wind-tunnel facility in VTI.
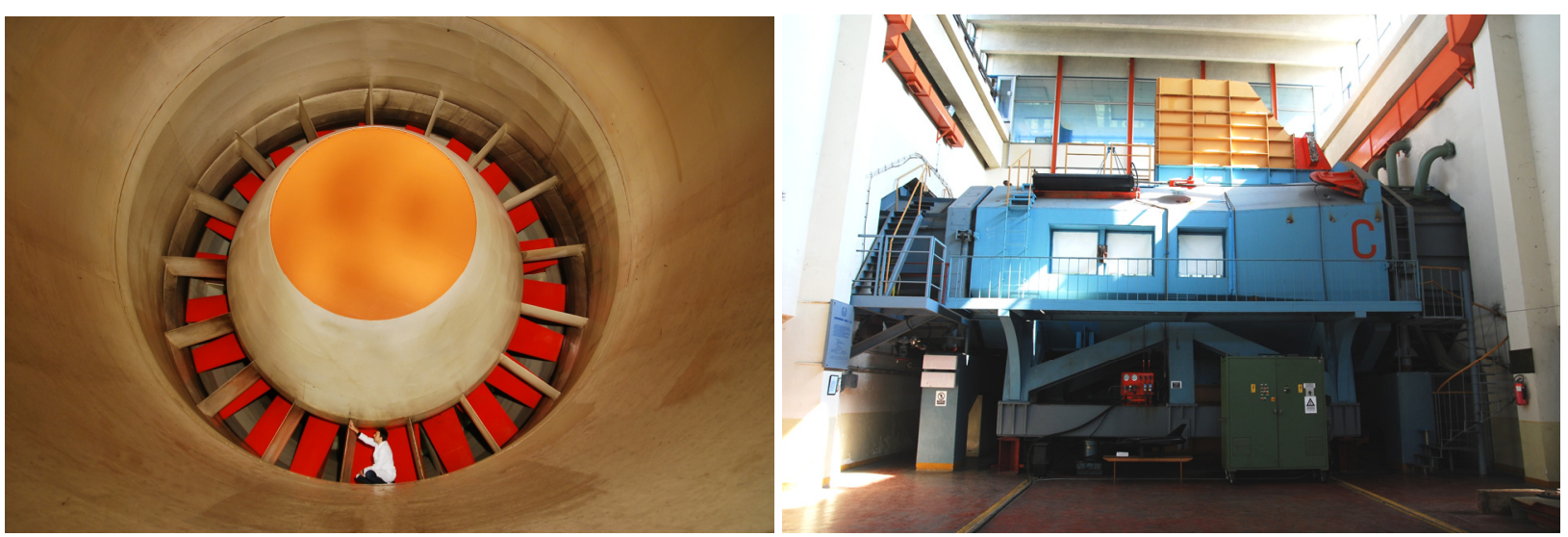

Figure 2. Variable-pitch-blades fan and tail-sting-support test-section of the T-35 wind-tunnel.
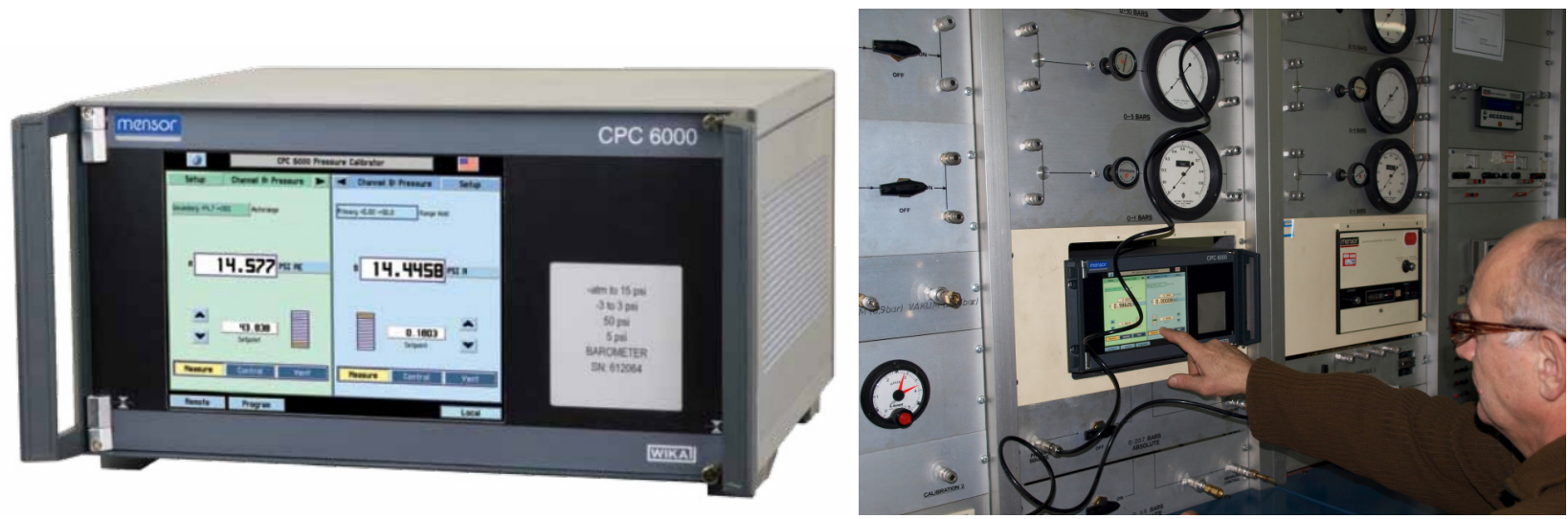

Figure 3. Mensor CPC6000 pressure calibrator in the VTI pressure laboratory.

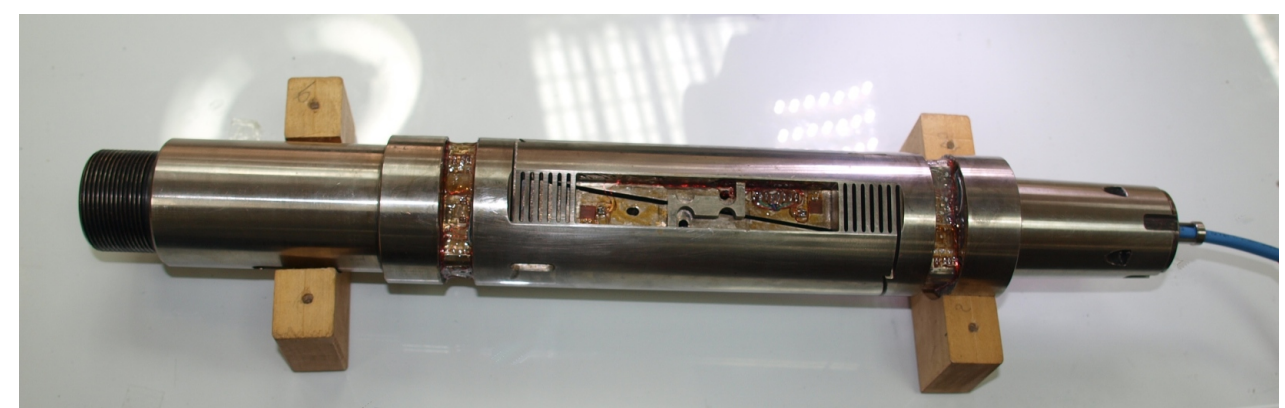

Figure 4. A $51 \mathrm{~mm}, 9 \mathrm{kN}$ monolithic internal wind tunnel balance produced in VTI.

All pressure transducers are calibrated in-situ at the beginning of each test. Reference pressure is supplied from a pressure calibrator with a transfer-pressurestandard accuracy of $0.01 \% / \mathrm{IS}-50$ in the pressure calibration laboratory of VTI. Calibration of the pressure transducers is being performed end-to-end, through the data acquisition and reduction system.
Stagnation temperature is measured by a RTD probe in the settling chamber. The accuracy of the transducer is better than $0.5 \mathrm{~K}$. Temperature transducer is checked by portable, well-calibrated thermometer.

A range of six-component force balances is available for use at the site, comprising both assembled and monolithic balances (Figure 4). 


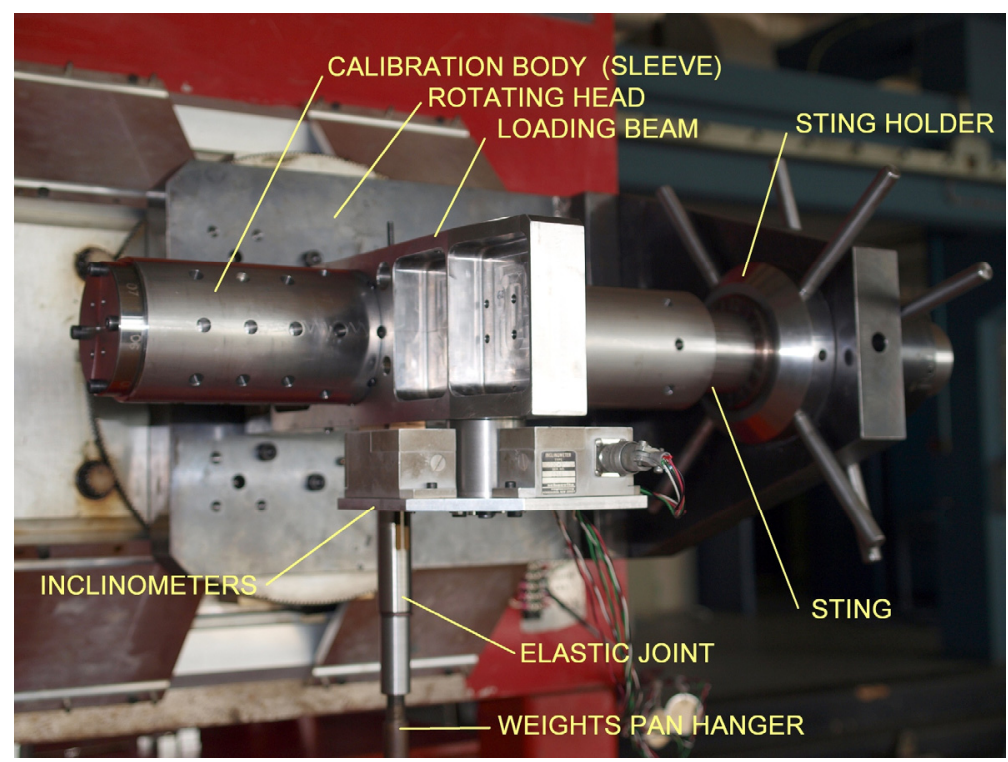

Figure 5. An internal balance on the upgraded composite-loadings balance-calibration rig in VTI.
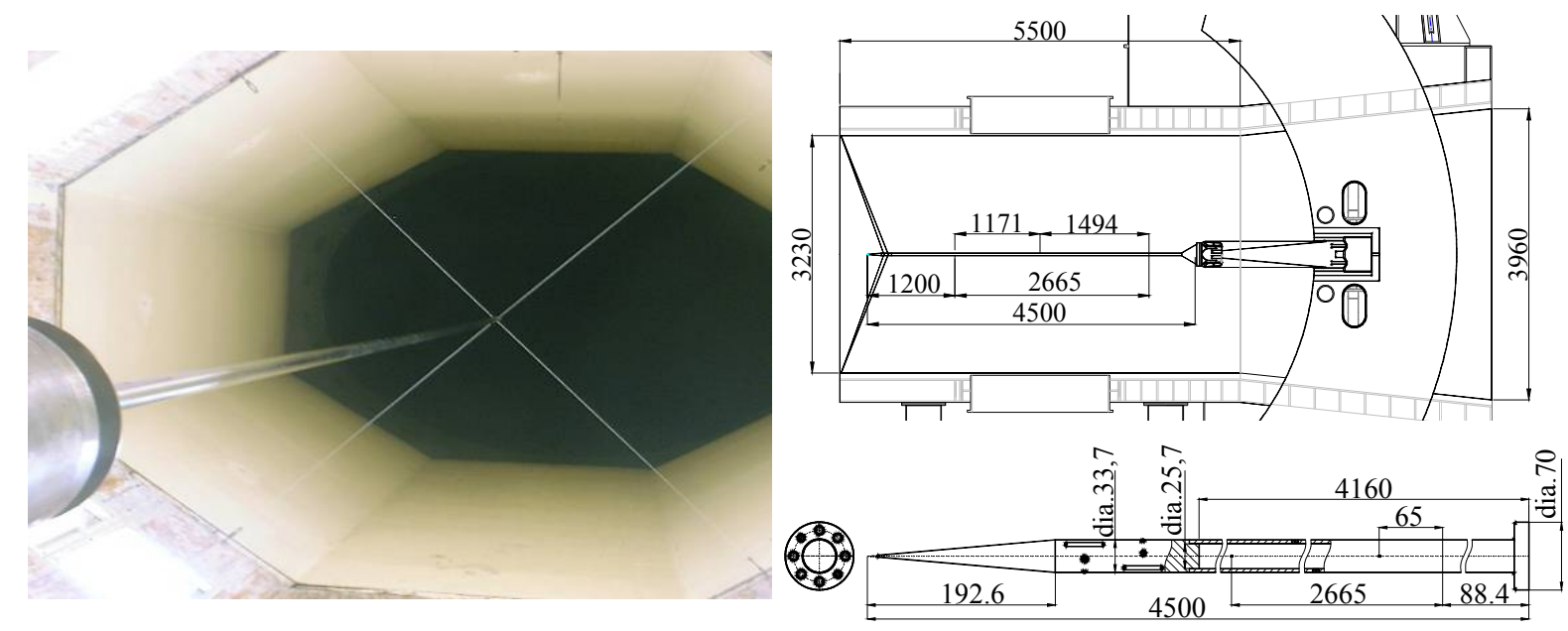

Figure 6. Centreline pole in the T-35 test section.
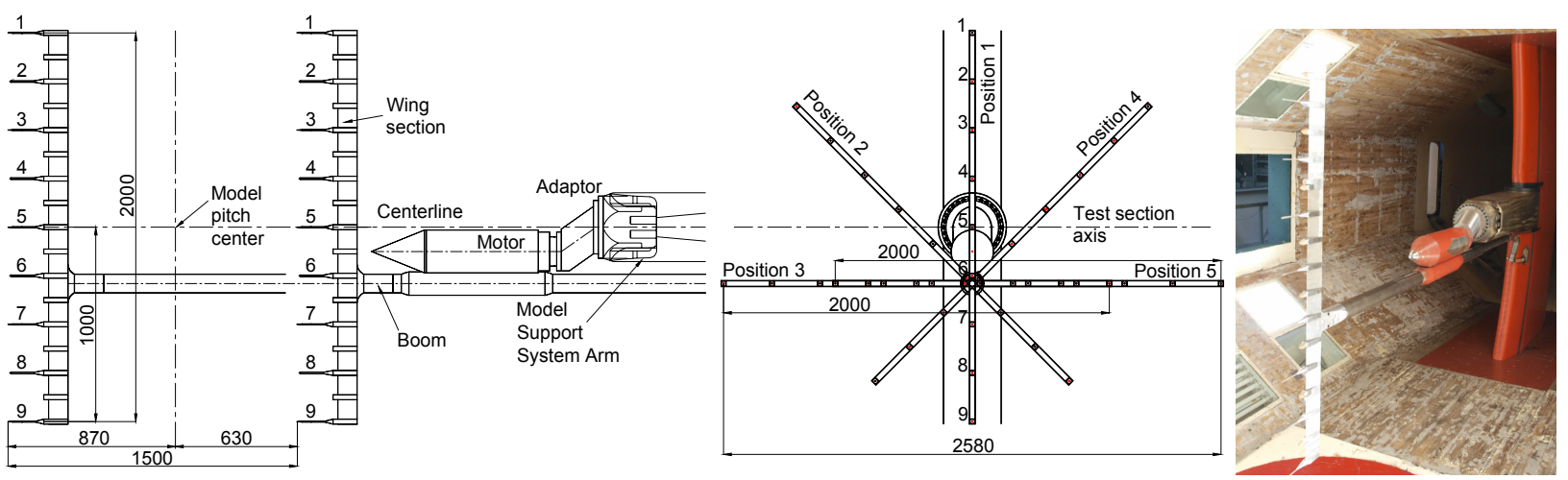

Figure 7. General arrangement of the traversing rake for the T-35.

Balances are calibrated in VTI's balance-calibration laboratory using the modern single-force-vector, globalregression method (Figure 5).

Calibrated weights are used as force generators. A recently-upgraded balance-calibration rig [15] enables relatively fast nonlinear calibrations, a typical calibration campaign taking 3 to 5 working days. Monolithic balances are typically calibrated to accuracy, based on two standard deviations of errors residuals of back-calculated calibration loads, between $0.05 \%$ and
$0.1 \%$ of F.S. component loads. A typical accuracy of assembled balances is between $0.1 \%$ and $0.2 \% \mathrm{~F}$.S.

Before each test, force balances installed in the wind tunnel are checked by applying reference weights to a balance mounted on a sting support, collecting measured signals of the balance components on the data acquisition system and comparing applied and measured balance components loads, in the range of forces expected in the test. A match of the applied and measured loads to within the measurement uncertainty 
of the balance (typically $0.1 \%$ F.S.) is expected. A check procedure, developed as a part of the upgrade of the balance calibration system [15], permits in-situ verification of a balance using a relatively small number of single-force-vector loading cases, thus speeding-up the preparation of wind tunnel tests.

Wind-tunnel test data are recorded using a 64channel, 16-bit-resolution, Neff 660/600/500 data acquisition system with an accuracy of $0.02 \%$ F.S. on analog input channels.

\section{CALIBRATION OF THE TEST SECTION}

Calibration of a wind tunnel test section includes determination of the Mach number and flow angularities profiles across and along the test-section, and determination of the background noise in the working flow, [16].

Recommendations had been given [6] to apply the appropriate combinations of pressures for different measurement situations in the process of test-section calibration. A scheme for measuring dynamic pressure at subsonic velocity of a flow is of a particular interest, when $q_{\infty}$ is usually determined through a dependency $q_{\infty}=q\left(p_{0}, M_{a v}\right)$, here the averaged Mach number $M_{a v}$ is based on the measurements of a field of the Mach number values for the test section, and total pressure $p_{0}$ is measured directly. The change in the average Mach number (and airspeed) along the axis of the tunnel is caused by any actual or effective convergence or divergence of the air stream. This change in velocity along the axis of the tunnel causes a variation in the static pressure and a correction must be applied to the drag to account for the buoyancy effect of any such staticpressure gradient. The airspeed generally varies slightly from point to point in a plane perpendicular to the tunnel axis. The usual procedure for correcting the test results for this variation in velocity is to use the average value of the dynamic pressure over the space occupied by the model in computing the model coefficients.

In order to evaluate the quality of the flow field in the T-35 test-section, two test-sets were conducted. First test-set comprised the measurements of the Mach number (static pressure) distribution along the centreline of the test-section using a centreline static-pressure pole (Figure 6), while the second test set comprised the measurements of the longitudinal and transversal distribution of the Mach number (static pressure), total pressure and flow angularities in the test-section using a multi-probe traversing rake (Figure 7).

The static-pressure pole used was a $0.007 \%$ blockage centreline cone-cylinder shape, consisting of a $5 \%$ half/angle sharp cone followed by a cylinder 4.307 $\mathrm{m}$ long (see Figure 6). Total probe length was $4.5 \mathrm{~m}$.
Surface static pressures were sensed by forty-two 0.7 $\mathrm{mm}$ orifices, scanned by an electromechanical Scanivalve scanner. The probe test region is having longitudinal dimension of $2.665 \mathrm{~m}$ about pitch centre of the test section, from about $1.171 \mathrm{~m}$ behind to $1.494 \mathrm{~m}$ ahead of the pitch centre.

The traversing rake system was a simple wing section mounted on the end of a boom which was attached to the model support system and strut in the test section.

Nine pressure probes were mounted along the leading edge of the wing. A rack-and-pinion drive in the boom support traversed the wing axially during a windtunnel run. The system was fixed in the lateral direction, but was adjustable in roll plane to one of five positions prior to the test.

Traversing rake measurements of the Mach number and flow angularity were performed within the test region of the wind tunnel, defined as having lateral dimensions of $2.58 \mathrm{~m}$ and longitudinal dimension of 1.5 $\mathrm{m}$ about pitch centre of the test section. The rake traversed from about $0.87 \mathrm{~m}$ behind to $0.63 \mathrm{~m}$ ahead of the pitch centre and spans $2.0 \mathrm{~m}$ of the flow width. The roll angle of the rake was adjustable to one of five positions 1 to 5 , with roll angle $0^{\circ}, \pm 45^{\circ}, \pm 90^{\circ}$.

The rake operated in the following sequence: Initial position of the rake was with the fully-extended boom. With the wind-tunnel started and flow established, a switch initiated the probe traverse. When the boom fully retracted the main wind-tunnel control system stopped the wind-tunnel. Pressure measurements were taken during the travel of the rake.

Flow angularities were measured using four pyramidal pressure probes (Figure 8) that measured flow direction in two orthogonal planes (probes marked as 2, 4, 6 and 8). Small-range piezo-resistive differential pressure transducers having $7 \mathrm{kPa}$ range and $0.05 \%$ F.S. nonlinearity and hysteresis were pneumatically connected to the vertical-plane pair of measuring orifices on the probe. Transducers of the same type were connected to the horizontal-plane pair of measuring orifices. Transducers were installed in the model support system.

Static pressures in the model test region were measured by the cone-cylinder probes (Figure 9) with a small tip angle. The probes used were built as a universal static- or total-pressure probe and had a tip that could be detached for the purpose of converting the probe into a total-pressure probe (the static-pressure orifices were plugged by adhesive tape in this configuration). Reference side of the transducers were connected to the measurement port for static pressure or stagnation pressure of the primary measurement system.

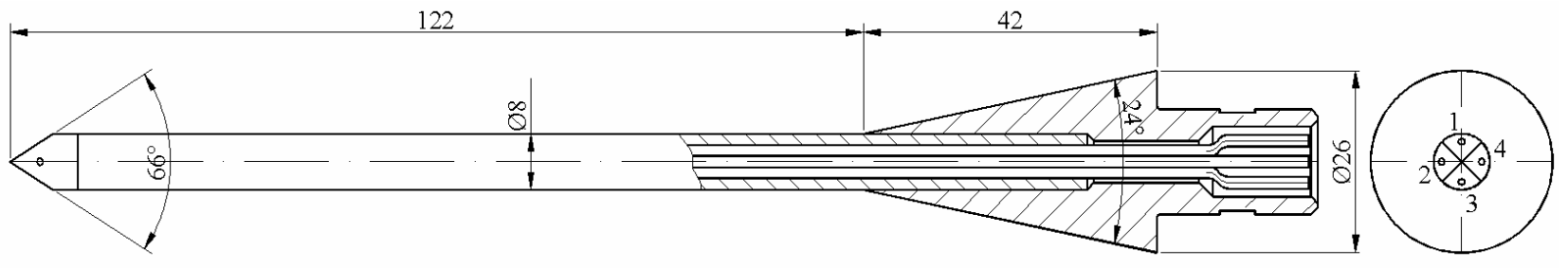

Figure 8. The pyramidal flow angle probe with the vertical- and horizontal-plane pair of measuring orifices. 


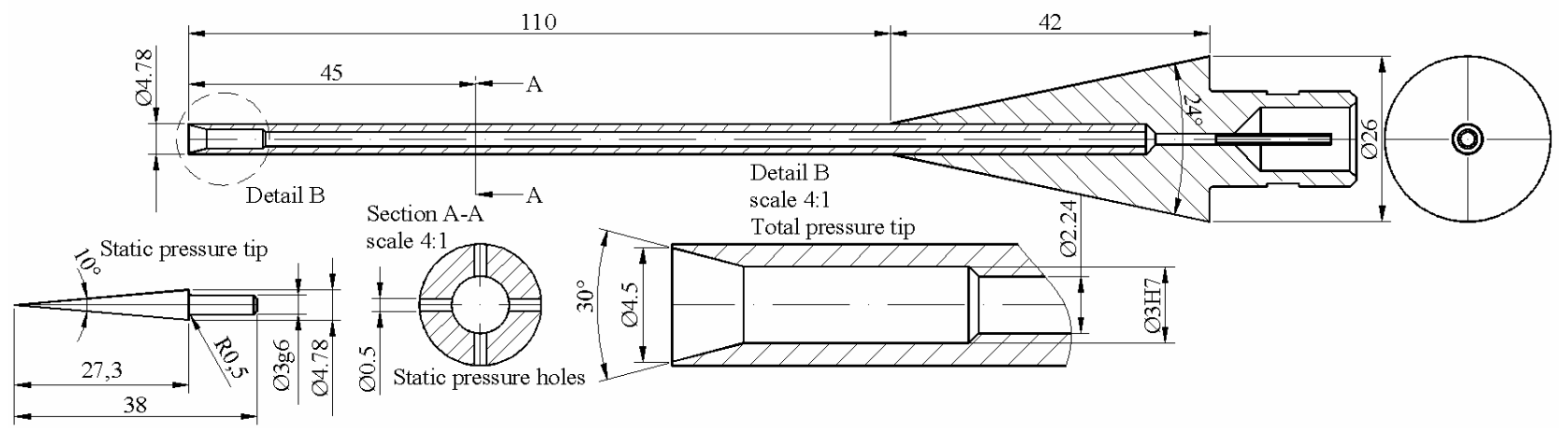

Figure 9. A universal static or total pressure probe.

\section{TESTS OF STANDARD WIND TUNNEL MODELS}

Standard wind tunnel models (also known as calibration models) are used to verify the complete measurement chain in a wind-tunnel. They are relatively simple objects of known aerodynamic characteristics and easilyreproduced geometry, so that repeatability of the shape of models manufactured for various facilities can be maintained. More specifically, standard wind-tunnel models are used for confirmation of the reliability of the data from a new wind-tunnel by comparison with the results from other wind-tunnel facilities, providing baselines for correlation of the results from different wind-tunnels, checkouts of data repeatability over time, [10]. Besides, the results from the wind-tunnel tests of standard models are used as test cases for verification of the computational-fluid-dynamics (CFD) computer codes. VTI is among the laboratories that have adopted the practice of periodical testing of standard models in order to provide a continued confidence in the reliability of measurements in their wind-tunnels.

There are several 3D "standard" wind tunnel models which have been tested at subsonic speeds, ranging from simple missile shapes to high-tech complicated airplanes. Among them the AGARD-B model, intended primarily for the measurement of aerodynamic forces and moments, has become the most popular by far. Initially designed for the supersonic wind-tunnels, the AGARD-B configuration has since been tested in many wind-tunnels at a wide range of Mach numbers, ranging from subsonic to hypersonic, and is one of the configuration selected by VTI for the periodic wind tunnel checkouts. Another model configuration used by VTI is a somewhat lessknown ONERA-M generic transport-aircraft shape.

\subsection{AGARD-B models}

AGARD-B standard model is a body-wing configuration representing a generic winged missile or highspeed airplane, [17][18]. The body is an 8.5 diameterslong solid of revolution with an ogive nose and a cylindrical rear part, and the wing is a delta with a span of four body diameters, (see Figure 10). Its standard support sting has a diameter of 0.5 model body diameters and a length of at least 3 body diameters. Reference area for the calculation of the coefficients is the theoretical triangular-wing area. Reference length for the pitching-moment coefficient is the mean aerodynamic chord (m.a.c.) while the reference length for the yawing- and rolling-moment coefficients is the wing span. Data are reduced to a model aerodynamic centre (a.c.) at $50 \%$ of m.a.c. Test data are presented in the wind-axes system [19] as 'forebody' aerodynamic coefficients, i.e. with the base axial force subtracted from the total axial force before converting data to the wing axes.

AGARD-B was selected as a standard model for periodic checkouts of the quality of measurements in a number of wind-tunnels, [17][18][20], including those in VTI.

Confidence in the validity of the standard AGARD-B test-data obtained in the T-35 wind-tunnel of VTI was established based on the within-facility and inter-facility comparisons, [14][21][22]. Two AGARD-B models, with diameters of $115.8 \mathrm{~mm}$ and $178 \mathrm{~mm}$, presenting frontal blockages of $0.1 \%$ and $0.24 \%$, respectively at zero incidence angle are periodically tested in the T-35 windtunnel. The $115.8 \mathrm{~mm}$ dia. Model (Figure 11), produced by Boeing, is physically the same model that had earlier been tested in the NRC/NAE 5ft wind-tunnel in Canada and several wind-tunnels in the United States and other countries. This model is also periodically tested in VTI's T-38 $1.5 \mathrm{~m} \times 1.5 \mathrm{~m}$ trisonic wind-tunnel, [22]. The 178 $\mathrm{mm}$ dia. model was produced by VTI, [23].

In tests of the $115.8 \mathrm{~mm}$ dia. model, aerodynamic forces were measured using a VTI-produced monolithic internal six-component strain gauge balance. In tests of the $178 \mathrm{~mm}$ model, aerodynamic forces were measured using an Able/Task assembled internal six-component strain gauge balance.

\subsection{ONERA M4 model}

ONERA has designed the " $\mathrm{M}$ " family of the wind tunnel standard models for subsonic and transonic wind tunnels [26-28]. The models represent generic transport-aircraft shapes, with swept back wings, horizontal stabilizer and tail (Figure 12) [23]. Models are produced in different sizes, ranging from "M1" with a fuselage diameter of 36 $\mathrm{mm}$ and a wing span of $287 \mathrm{~mm}$ through "M5" with a diameter of $124 \mathrm{~mm}$ and a wing span of $982 \mathrm{~mm}$ to a model with a wing span of $2.45 \mathrm{~m}$ [28] that would correspond to "M12". Typical measurements on the models include determinations of forces and moments by an internal balance and measurements of pressure distribution on several sections on the wing.

Airfoils of the wing, the horizontal and vertical tails are symmetrical, with a maximum thickness of $10.5 \%$ at 
the $37.5 \%$ of the chord. The angle between the leading edge of the swept wing and the fuselage axis is $30^{\circ}$, aspect ratio of the wing is 7.31 , and its installation angle is $4^{\circ}$ in relation to the fuselage axis. The angles between the leading edge of the horizontal and the vertical tail, and the fuselage axis are $37.5^{\circ}$ and $47.5^{\circ}$, respectively. The cylindrical fuselage has three sections. The wing and the horizontal tail have dihedral angle of $3^{\circ}$ and they are not warped.

The ONERA-M model tested in the T-35 wind tunnel (Figure 13) was of "M4" size with a fuselage diameter of $102 \mathrm{~mm}$. The model was produced by INCREST, Romania, and had previously been tested in the T-38 trisonic wind tunnel of VTI.
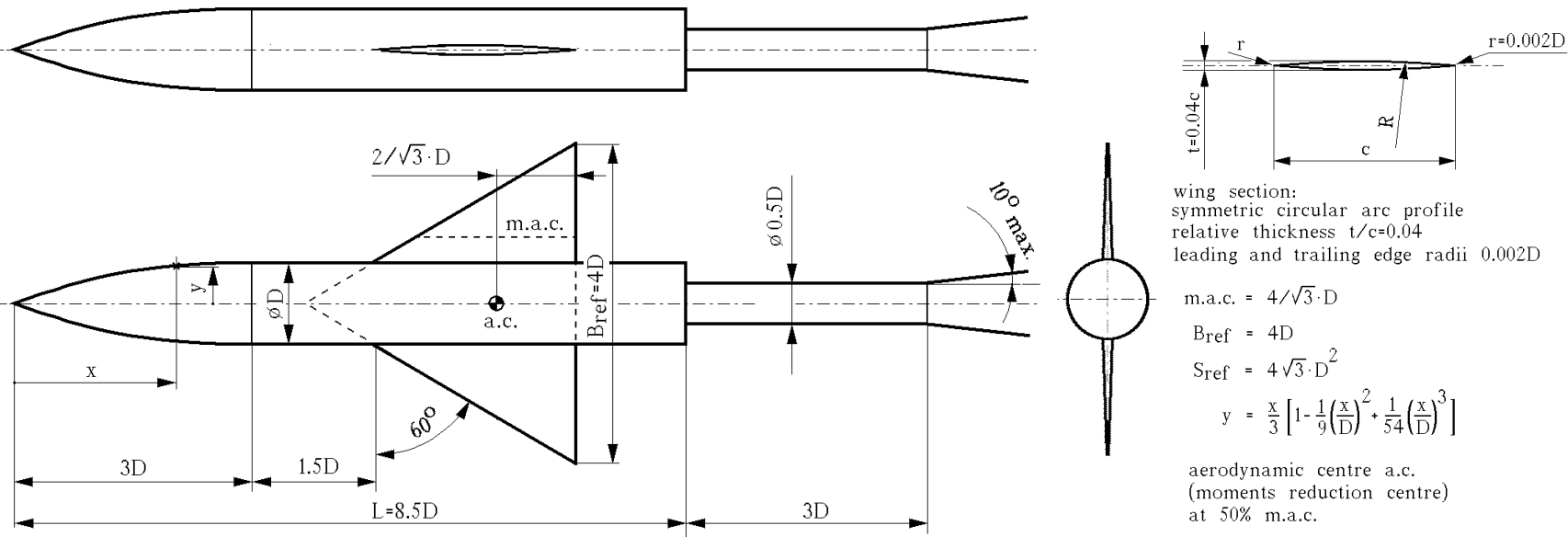

Figure 10. Geometry of the AGARD-B standard model and its sting fixture, [22].
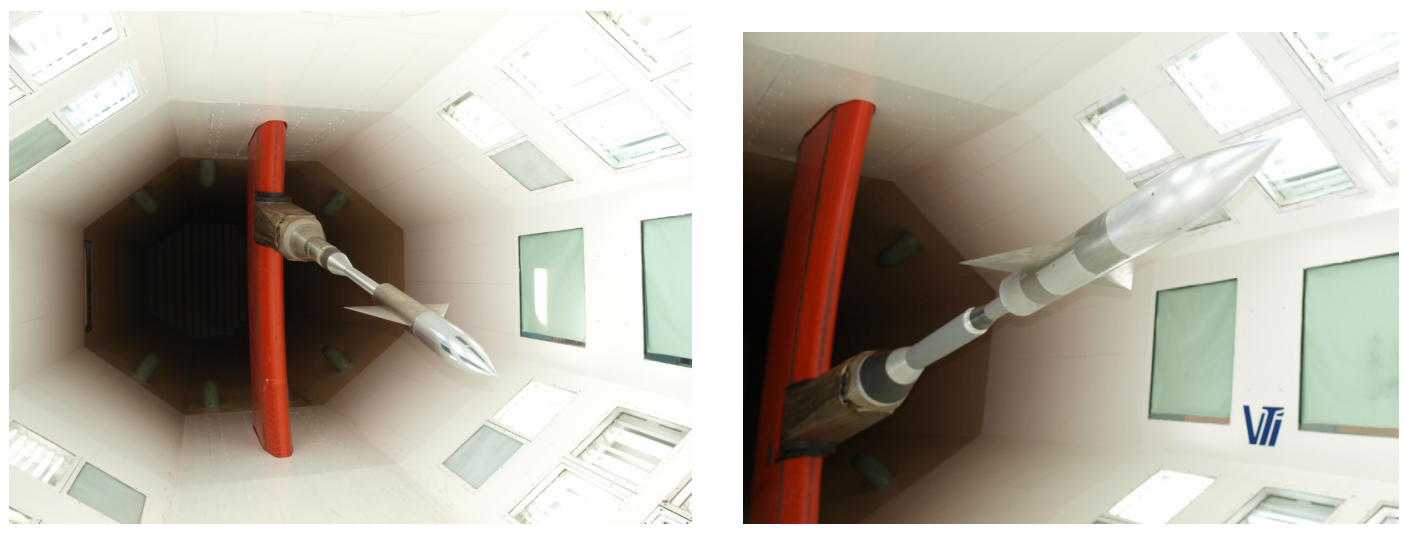

Figure 11. Two AGARD-B models (115.8 and $178 \mathrm{~mm}$ dia.) in the T-35 wind-tunnel.
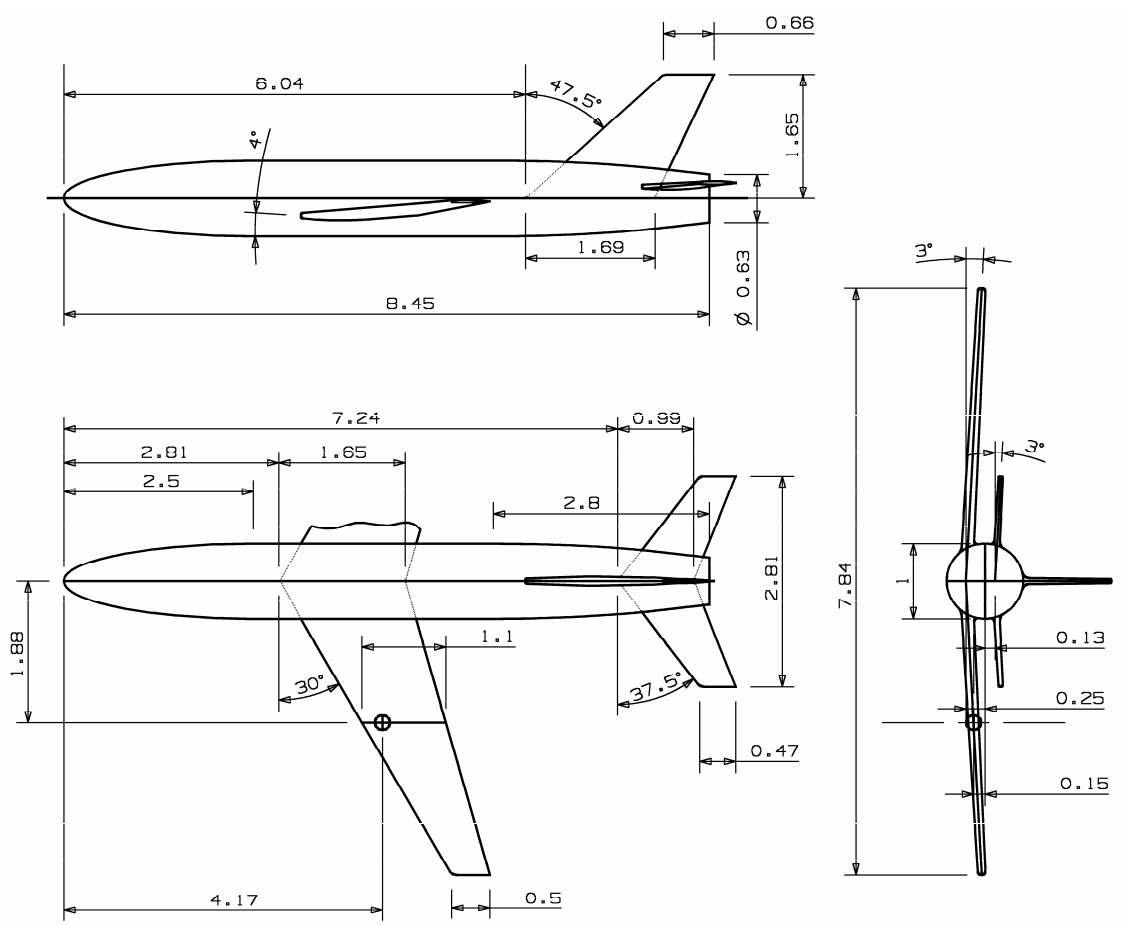

Figure 12. The basic geometric characteristics of the ONERA M standard model. 


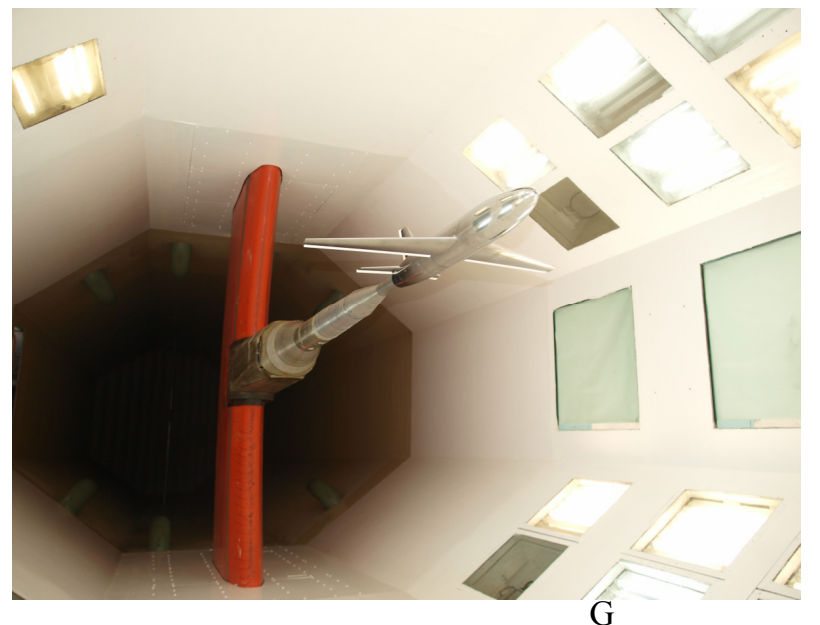

Figure 13. ONERA M4 calibration model (102 $\mathrm{mm}$ dia.) in the T-35 wind tunnel.

\section{TESTS OF STANDARD WIND TUNNEL MODELS}

\subsection{AGARD-B models}

As a sample of typical instrumentation-calibration results related to the tests in the T-35 wind tunnel, the summary of the calibration of an internal wind tunnel balance is presented in Figure 14 in the form of backcalculated error residuals in the calibration data-set.
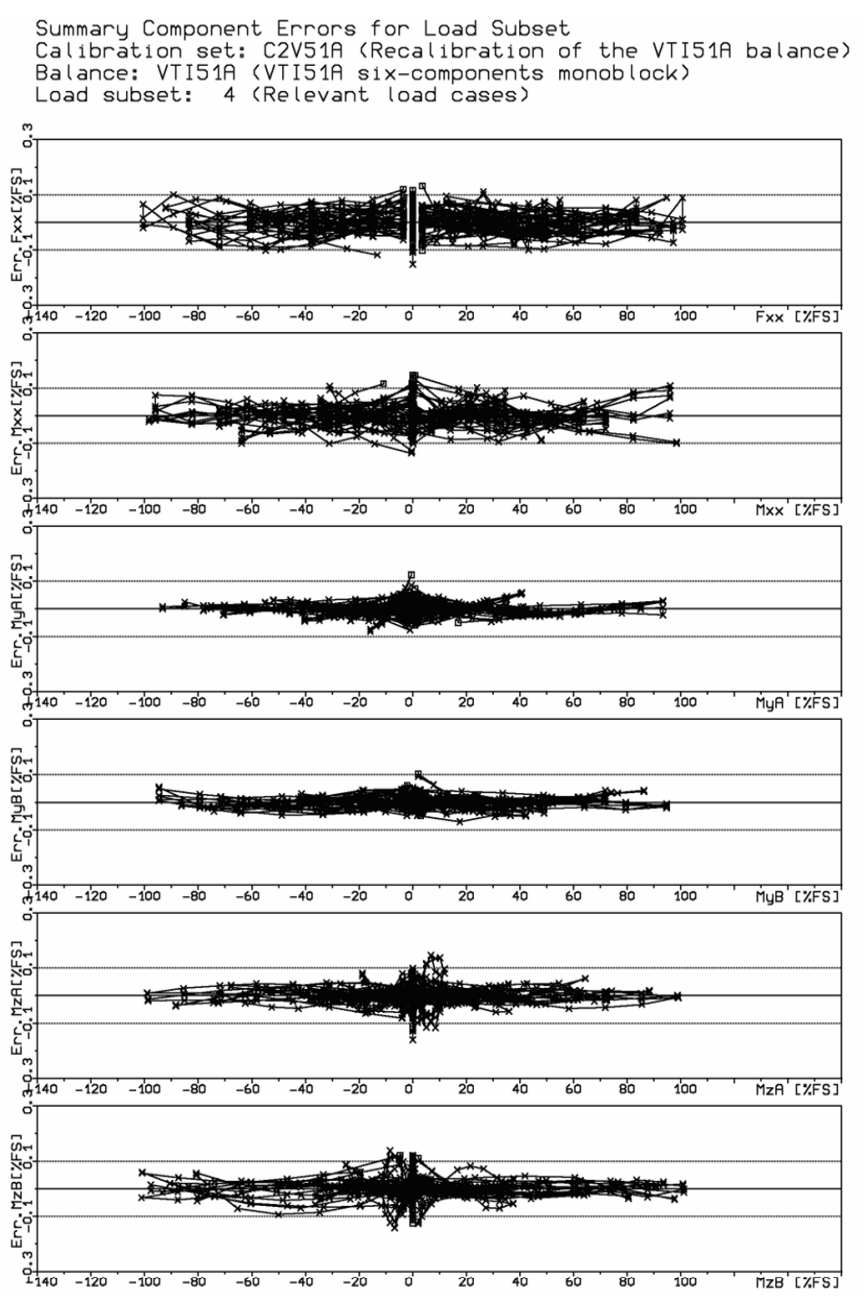

Figure 14. Error residuals in the calibration checkout of a monolithic six-component internal wind tunnel balance in VTI.
The calibrated balance was a VTI-produced $51 \mathrm{~mm}$ diameter, six-components monolithic internal wind tunnel balance of the "moments" type with normal force F.S. range of $9 \mathrm{kN}$, axial-force F.S. range of $2 \mathrm{kN}$ and pitching-moment F.S. range of $0.8 \mathrm{kNm}$. The loading method was simultaneously loading several balance components by single force vectors and the data were processed using global regression over the complete data set that comprised 85 loading series with about 1200 composite-loadings data points. Measurement uncertainty of the balance, obtained on the basis of two standard deviations of back-calculated error residuals, was $0.07 \%$ F.S. for the axial force, $0.08 \%$ F.S. for the rolling moment, $0.04 \%$ F.S. for the fore- and aft pitching moments, and $0.06 \%$ F.S. for the fore and aft yawing moments. These results are typical [7] for internal wind tunnel balances and confirm the quality of the instrumentation and the calibration procedure.

\subsection{Test-section calibration results}

Results of the measurement of the Mach number distribution along the test section centreline with the static-pressure pole are given in Figure 15. Position of the pressure orifices on the pole relative to the test section centre is identified as $x$. Measurement showed a satisfactory Mach number distribution along the test section centreline for all Mach numbers, the double standard deviation being $2 \sigma_{M}<0.005 M$, given in Figure 16 , satisfying the so-called Jackson's criterion [22] for subsonic wind tunnels.

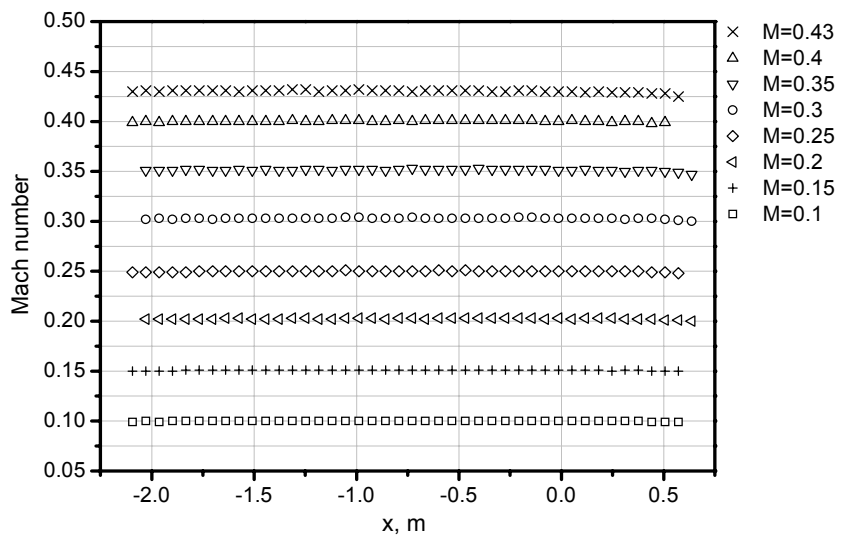

Figure 15. Mach number distribution along the centerline of the T-35 test section.

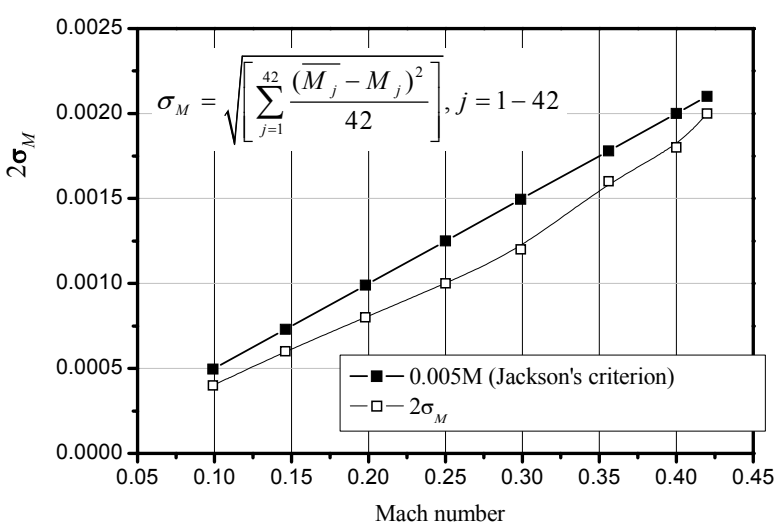

Figure 16. Mach number standard deviation. 
Sample results from measurements of flow angularities, Mach number, static and total pressures in the T-35 test section at Mach 0.2 obtained by the traversing rake (rake in "position 1", see Figure 7) are given in Figure 17 and Figure 18.

Summary results of the calibration of the test section are: longitudinal and transversal spatial Mach number distributions in the term of double standard deviations $2 \sigma_{M}$ are better than $0.005 M$ for all Mach numbers; calculated Mach number corrections are up to 0.008 . Flow angularity is better than $0.25^{\circ}$ in vertical and horizontal planes, for all Mach numbers. Calibrations showed that performances of the wind-tunnel are up to design specifications.

\subsection{AGARD-B test results}

Examples of results from the tests of AGARD-B standard model are presented for Mach numbers 0.1 to 0.4. As customary for the AGARD-B model, test results are given in a wind-axes system located in the reference point of the model at $50 \%$ m.a.c, $5.943 \mathrm{D}$ downstream of the model nose. The $\mathrm{X}$ axis was parallel to the air velocity vector and in the same direction (toward the end of the model). The $\mathrm{Z}$ axis lay in the flow plane and was normal to the $\mathrm{X}$ axis. The $\mathrm{Y}$ axis completed the left-handed axes system.

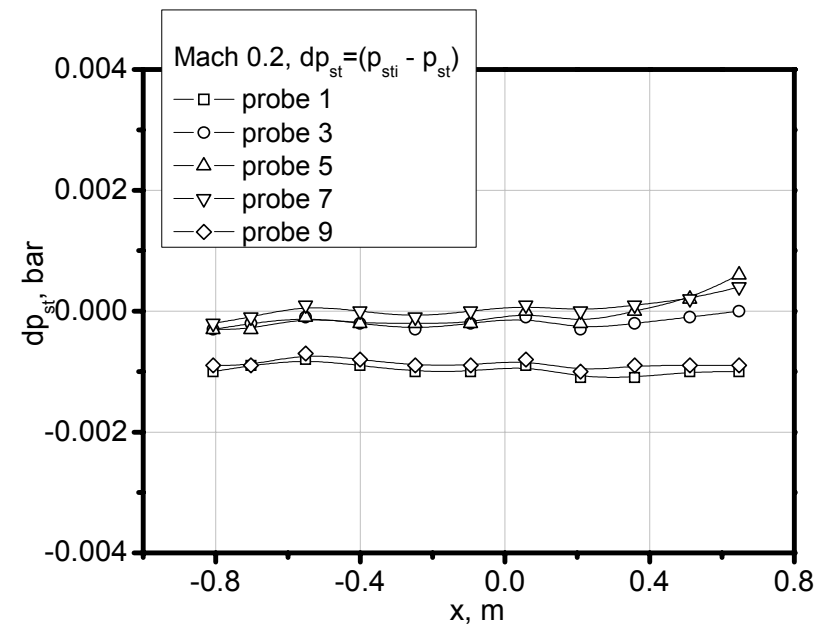

Test-data of the model in both the upright and the inverted positions, presented in the wind-axes system, show the test section symmetry based on determined flow angularities in the vertical and the horizontal planes. It should be noted that the angle of attack in the wind-axes system is defined as positive if the air stream attacks the bottom of the model. Data in a non-rotated wind-axes system from the model-upright run are to be compared with the data from the model-inverted run to check the model symmetry, [22].

Analysis of the measured aerodynamic coefficients from the point of symmetry was done for two Mach 0.4 runs of the $115.8 \mathrm{~mm}$ dia. model in the model-upright and model-inverted positions. Compared aerodynamic coefficients are given in graphs in Figure 19. Aerodynamic coefficients and differences between coefficients at the model zero angle of attack are given in Table 1. Data in a wind-axes system from the modelupright run were compared with the data at identical aerodynamic angles from the model-inverted run $[14][22][29]$ to check test section symmetry.

Test results showed a good correlation between the two runs, the differences being practically bellow the accuracy of the wind-tunnel balance used. Therefore, a good symmetry of the test section, taking into account the determined flow angularity, was confirmed.

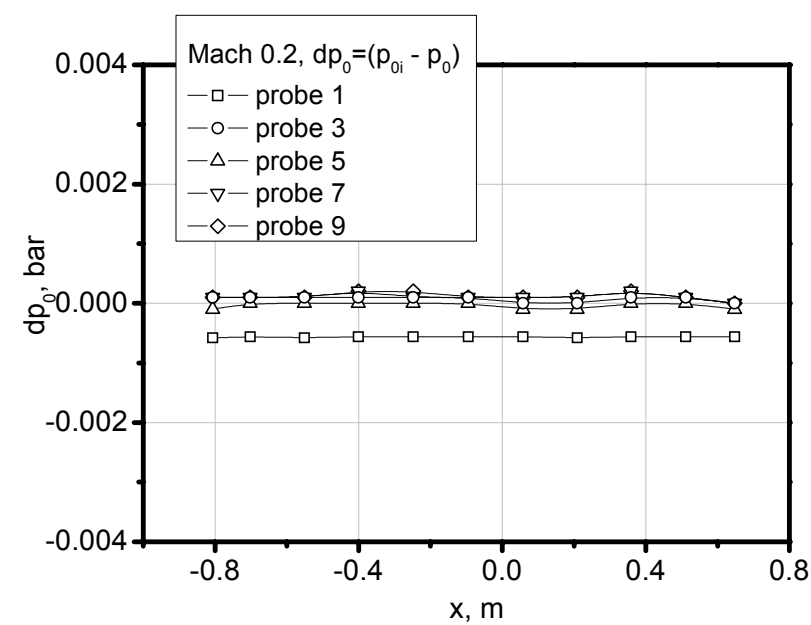

Figure 17. Static pressure and total pressure distribution in the model test region of the T-35 test section at Mach 0.2 .
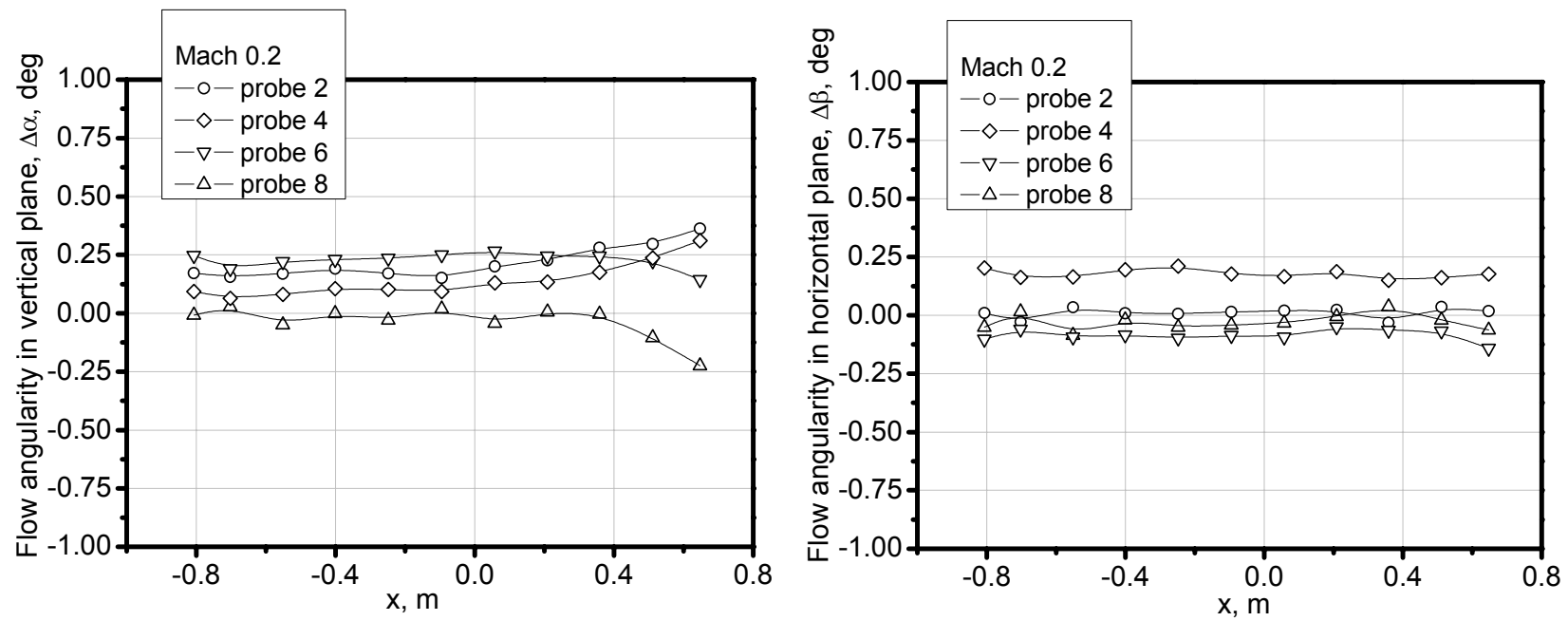

Figure 18. Flow angularities in the vertical and horizontal planes in the model test region of the T-35 test section at Mach 0.2 . 

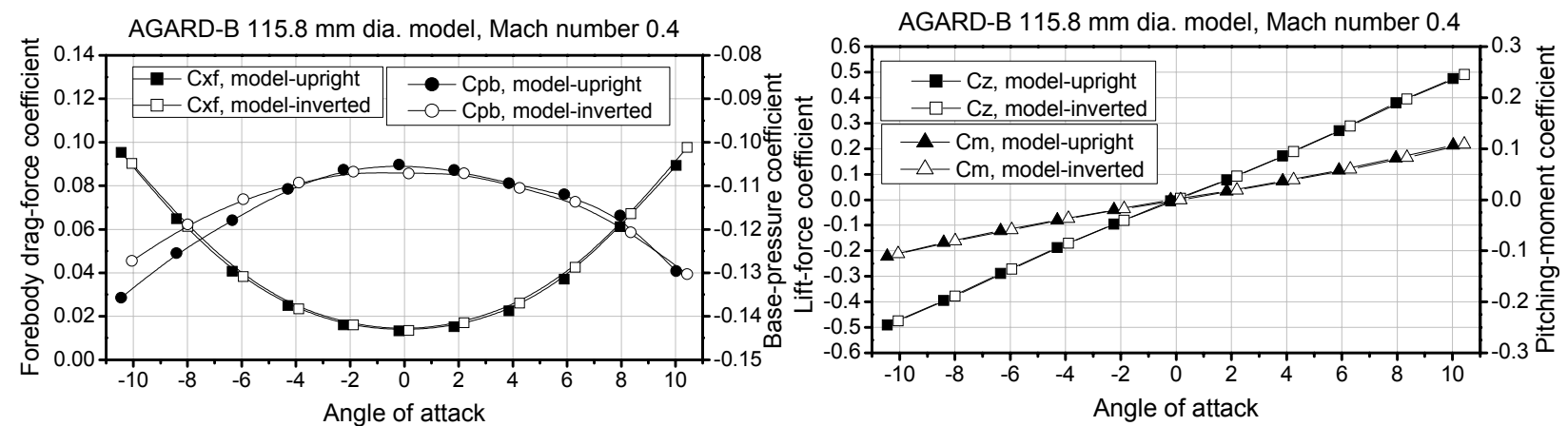

Figure 19. Aerodynamic coefficients, AGARD-B 115.8mm, T-35, Mach 0.4.
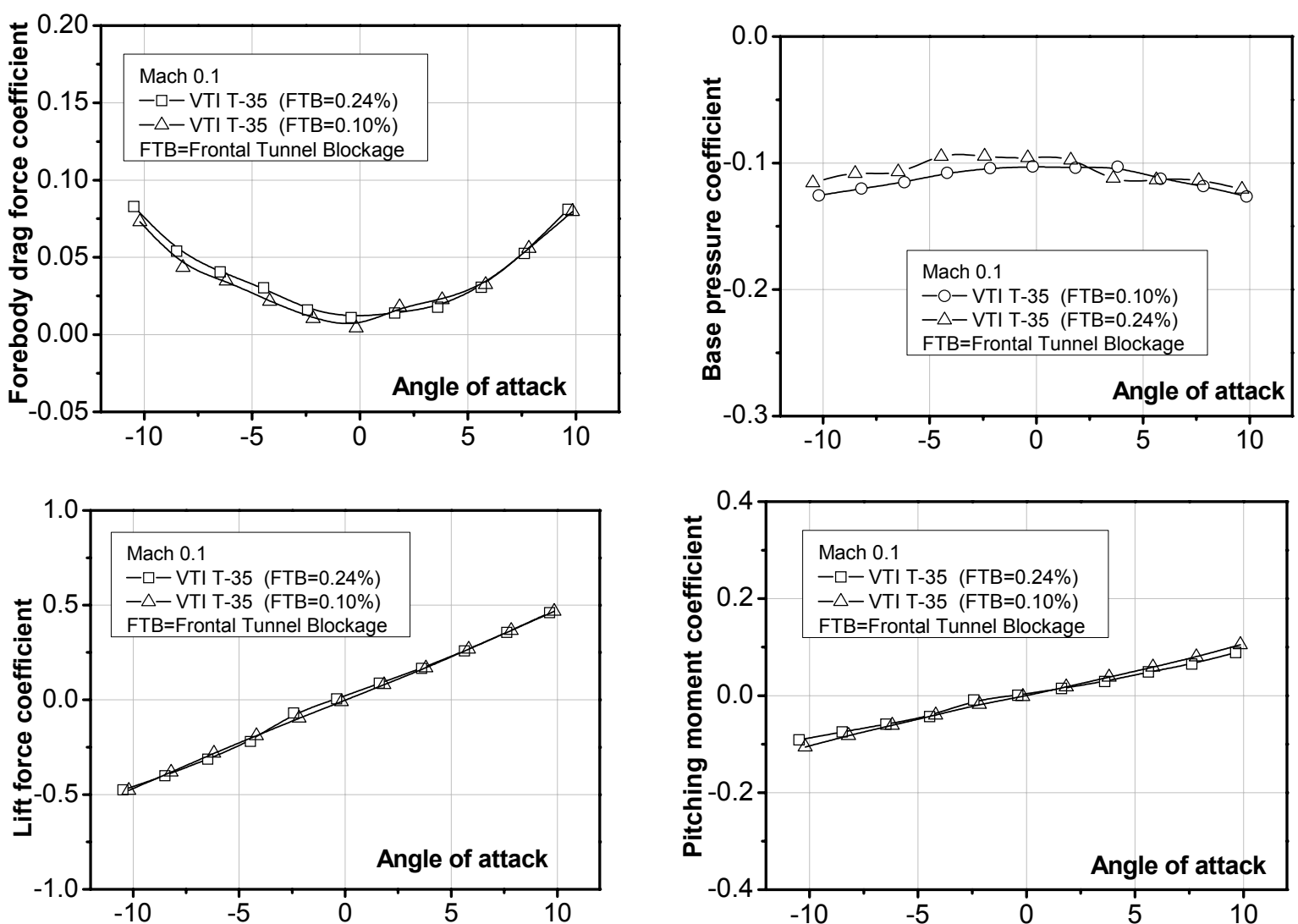

Figure 20. Aerodynamic coefficients, AGARD-B $115.8 \mathrm{~mm}$ dia. and $178 \mathrm{~mm}$ dia. models, the T-35 facility, Mach 0.1.

Wind-tunnel data uncertainty was considered in the form of repeatability from a few supposedly identical wind-tunnel runs of the $115.8 \mathrm{~mm}$ dia. model. The accuracy requirements for standard models wind-tunnel data were specified concerning three different categories [22] and only run-to-run data repeatability (regarded as a short-term repeatability) was monitored and assessed. As the $115.8 \mathrm{~mm}$ dia. model was tested in the T-35 facility for the first time, the long-term repeatability could not be obtained. Within-test data repeatability levels of cca. \pm 0.0005 in drag-coefficient measurement, better than \pm 0.01 in lift-coefficient measurement, and \pm 0.001 in pitching-moment coefficient measurement, were achieved. A good within-test data repeatability was established.

Within-facility correlation was done on the basis of two different model sizes $(115.8 \mathrm{~mm}$ dia and $178 \mathrm{~mm}$ dia.) at Mach 0.1 (see Figure 20). Also the $178 \mathrm{~mm}$ dia. model was tested in the T-35 facility for the first time and there were no relevant data from its earlier measurement. The presented data are from the comparison of the results at Mach 0.1 .

Table 1. T-35 wind tunnel test section symmetry check

AGARD-B model, Mach 0.4, Alfa $=0$, wind-axes system

\begin{tabular}{|l|l|c|c|c|c|c|}
\hline Run & $\begin{array}{l}\text { Model } \\
\text { position }\end{array}$ & $C_{D f}$ & $C_{L}$ & $C_{m}$ & $C_{p b}$ & $C_{D}$ \\
\hline$\# 1$ & upright & 0.0133 & -0.005 & 0.000 & -0.1051 & 0.0252 \\
\hline$\# 2$ & inverted & 0.0135 & 0.006 & 0.000 & -0.1072 & 0.0257 \\
\hline$\Delta \mathrm{C}=\mathrm{C} \# 1-\mathrm{C} \# 2$ & 0.0002 & 0.011 & 0.000 & 0.0013 & 0.0002 \\
\hline
\end{tabular}

The overall facility verification was done on the basis of inter-facility correlation, i.e. test-data from both AGARD-B models were correlated with those from the NRC/NAE 5ft, [21] the AEDC 4T and the T-38 windtunnel (Figure 21 - Figure 23), [30], where the same smaller (115.8 $\mathrm{mm}$ dia.) model was tested in all three wind tunnels. A very good correlation was found among the different-model-sizes test-data and among the testdata from different wind-tunnel facilities. 

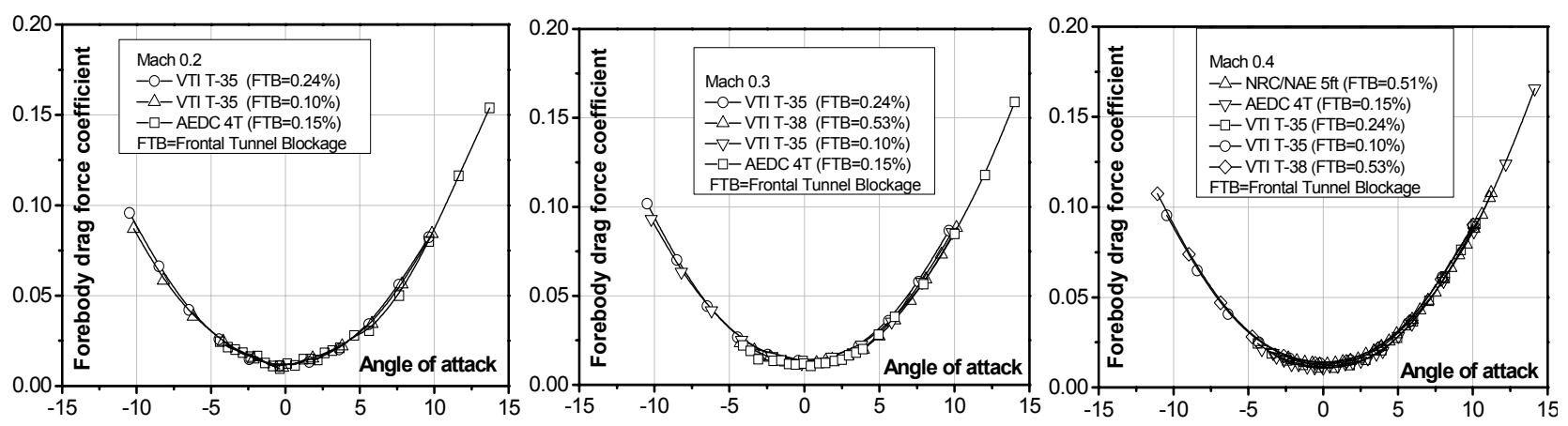

Figure 21. Inter-facility correlations: Forebody drag-force coefficient, AGARD-B model, Mach 0.2, 0.3 and 0.4.
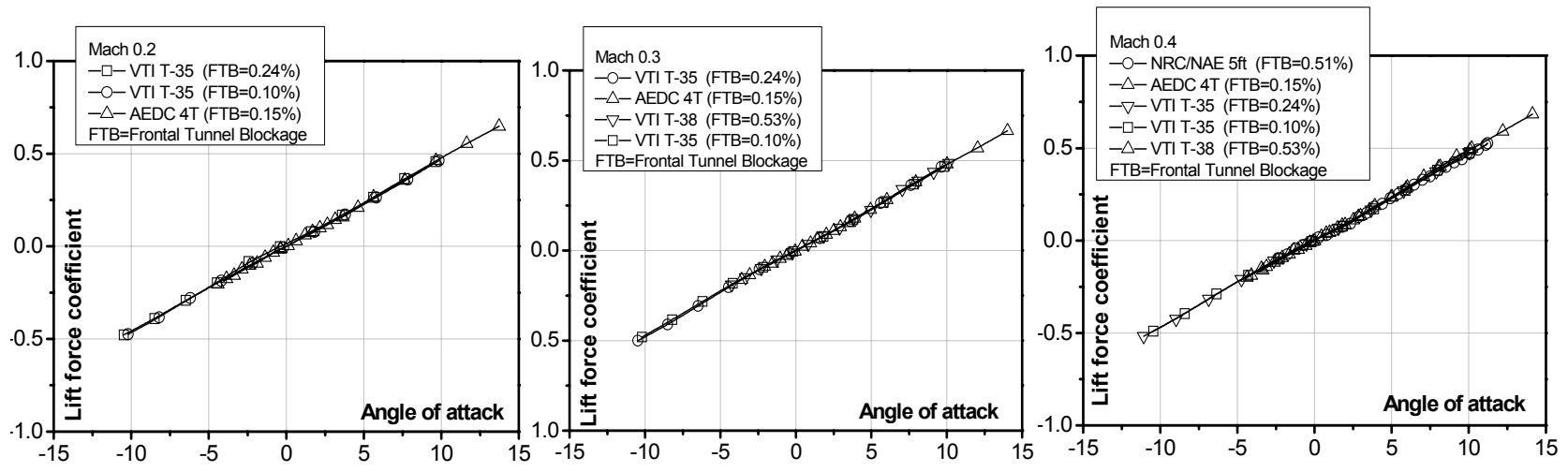

Figure 22. Inter-facility correlations: Lift-force coefficient, AGARD-B model, Mach $0.2,0.3$ and 0.4 .
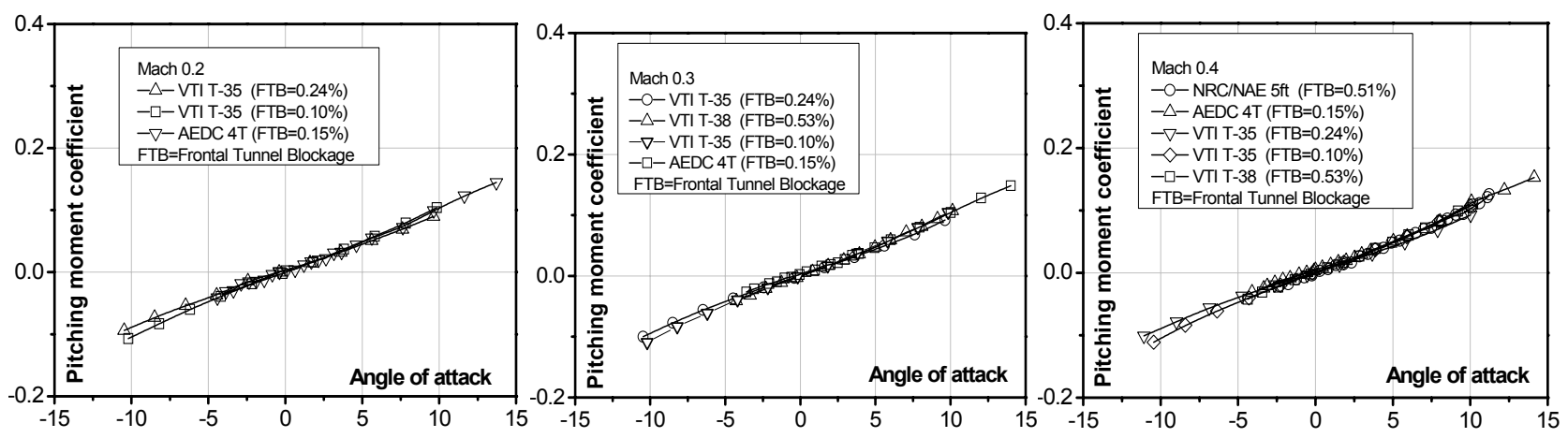

Figure 23. Inter-facility correlations: Pitching-moment coefficient, AGARD-B model, Mach 0.2, 0.3 and 0.4 .

\subsection{ONERA M4 test results}

The results are presented as axial force, normal force and pitching moment coefficients. Test results are given for the body axes system, located in the model reference point, at the distance of $425.56 \mathrm{~mm}$ downstream of the model nose. The reference length calculation of the pitching-moment coefficient was the mean aerodynamic chord $(112 \mathrm{~mm})$.

Analysis of the measured aerodynamic coefficients from the point of symmetry was done for two Mach 0.25 runs of the ONERA M4 model in the modelupright and model-inverted positions [24][25]. A good repeatability of the results of a model testing at $\phi=0^{\circ}$ and $\phi=180^{\circ}$ (Figure 24) is established, the deviations being attributed to the uncertainty of the internal balance used, which, because of the mechanical design of the model, had to be an assembled, Task-type one with accuracy somewhat lower than that of monolithic balances. Maximal deviation of a normal force value in these two measurements is observed at the angle of attack of $+3^{\circ}(8.52 \mathrm{~N}$ or $0.048 \%$ of balance F.S. load range). Maximal deviation of the axial force is observed at the angle of attack of $-6^{\circ}(5.808 \mathrm{~N}$ or $0.22 \%$ F.S.). Maximal deviation of a pitching moment value is 0.911 $\operatorname{Nm}(0.268 \%$ F.S. $)$, at the angle of attack of $+5^{\circ}$.

In the Figure 25 the graphs of normal force, axial force and pitching moment coefficients are shown. The results were obtained by testing at the Mach numbers $0.2,0.3$ and 0.4 at the zero model roll angle.

The presented tests of the ONERA M model in T-35 were the first test of this model in the T-35 facility, so the previous results were not available. An inter-facility comparison was made with the results from the tests of a M1 model at Mach 0.25 in the NRC/NAE 5ft windtunnel, under the same aerodynamic conditions, [26][30]. The comparison of the normal force, axial force and pitching moment aerodynamic coefficients is given in the Figure 26. The test results show a good agreement with the results of the tests in the NRC/NAE 5ft windtunnel. Good repeatability and small deviations of the results confirm the test quality. 

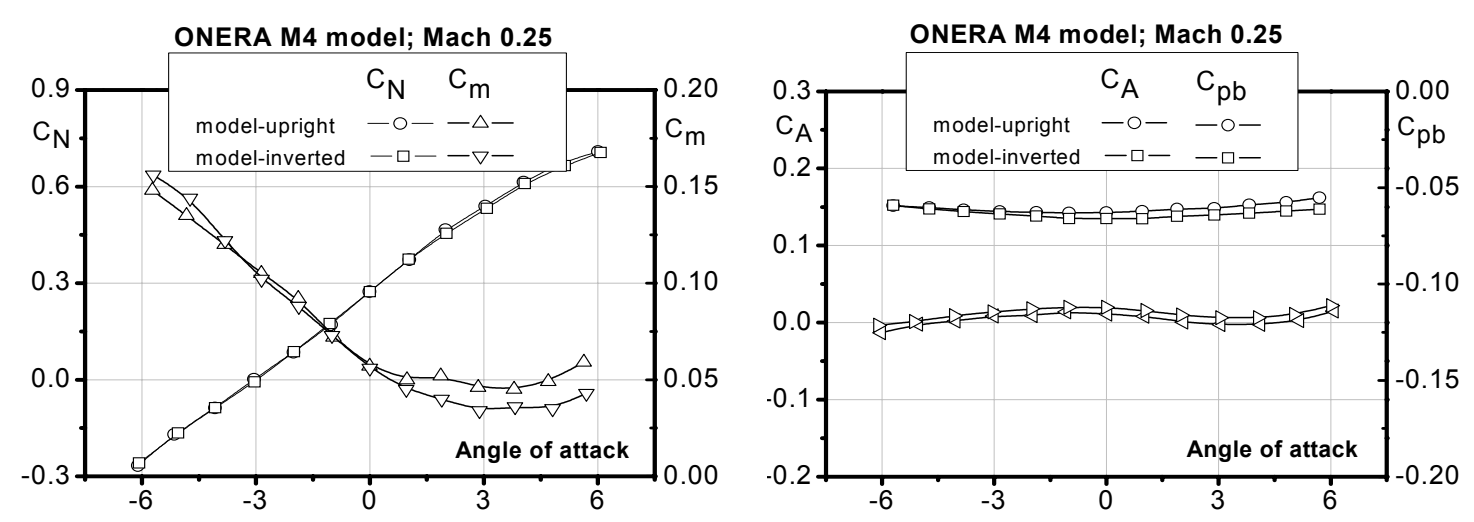

Figure 24. Aerodynamic coefficients, ONERA M4, T-35, Mach 0.25.
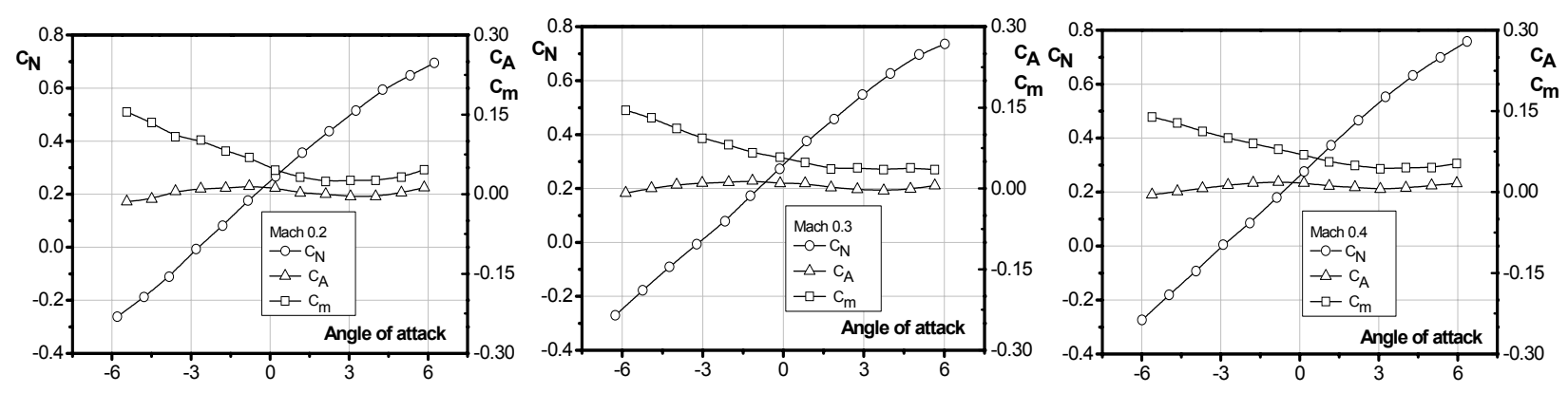

Figure 25. Aerodynamic coefficients, ONERA M4, T-35, Mach 0.2 up to 0.4 .
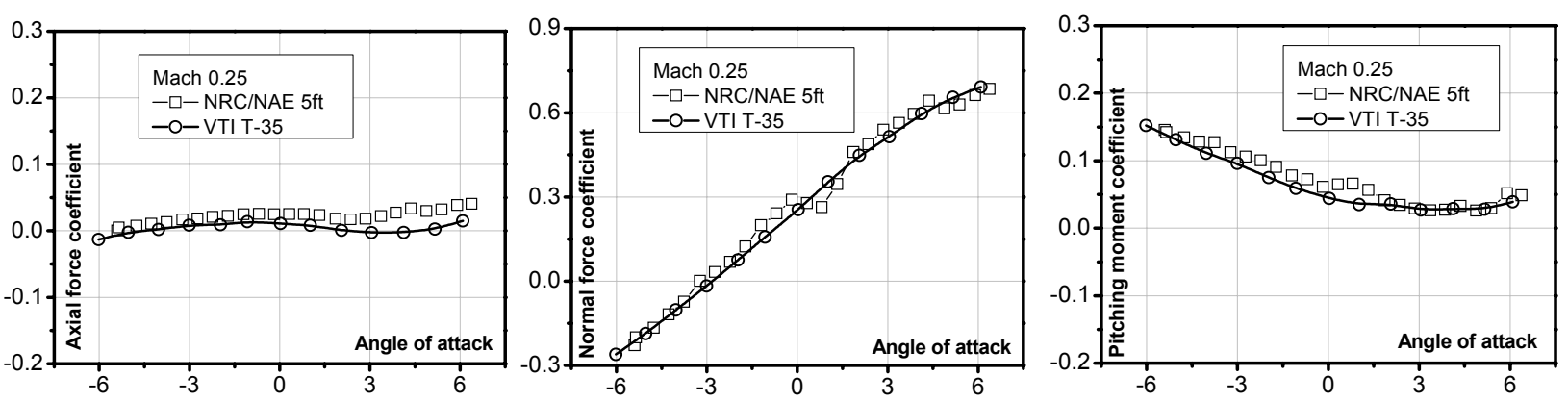

Figure 26. Inter-facility correlations: Aerodynamic coefficients, ONERA M4 model, Mach 0.25.

\section{CONCLUSIONS}

For a successful contribution of the wind tunnel tests in the development of aeronautical vehicles, it is essential that the level of quality of measurements and the uncertainties involved are assessed and understood. Also, it is important that accurate calibrations and verifications of all components of the measurement chain are established, maintained and statistically controlled throughout the lifetime of the wind tunnel.

VTI has undertaken to establish a framework of statistical monitoring, control and improvement of the wind tunnel measurement processes. As a part of this effort, the quality of the wind tunnel instrumentation and the methods of its calibration are being improved, and a series of wind tunnel tests in the T-35 large lowspeed wind tunnel has been performed, comprising test section calibrations and verifications through testing of the standard models.

The calibration of the wind tunnel test section provided an insight into the basic characteristics of the flow and their variations across the space of the test section. All considered flow quality factors, such as mean flow variations, Mach number distribution, total and static pressure distribution and flow angularity were within the expected levels. The variation of a total pressure in the test section was below $0.1 \%$, equivalent to a velocity variation of less than $0.05 \%$.

Test of the standard (calibration) models (AGARDB and ONERA M4) with well documented aerodynamic characteristics in the subsonic flow regime, and subsequent comparison of the results with those from other wind tunnel facilities served to confirm the overall accuracy of measurements in the T-35 facility and to confirm confidence in the results obtained [31]. This test was actually an important 'combined' check of the calibration status of the wind-tunnel because a good correlation of the test results with the reference results could be obtained only with a good wind-tunnel calibration.

A summary conclusion based on the performed series of tests is that they have confirmed a good quality of measurements in the T-35 wind tunnel facility [32]. Recently established measurement-quality check procedures have become a regular practice in this wind tunnel. In order to be able to maintain and control the 
measurement quality the procedures have to be systematically applied in the future, the relevant parameters must be periodically checked and systematically documented.

Constant effort is being made in the upgrading of all measuring systems of the facility. Besides, monitoring of all the flow quality parameters in the frame of modern approaches and contemporary procedures enables the test facility to stay a state-of-the-art and reliable link in the design and development chain of the future subsonic flight objects.

\section{REFERENCES}

[1] Anderson, J.D.Jr.: Fundamentals of Aerodynamics, McGraw-Hill, USA, 1991.

[2] Barlow, Jewel, B., et al,: Low Speed Wind Tunnel Testing, Wiley, New York, 1999.

[3] Katz, J., Plotkin, A.: Low-Speed Aerodynamics, McGraw-Hill, Singapore, 1991.

[4] Tropea, C., et al,: Springer Handbook of Experimental Fluid Mechanics, Berlin, 2007.

[5] AIAA Recommended Practice for Wind Tunnel Testing — Part 1, R-092-1-2003e; Part 2, R-092-22003e, AIAA Standards, 2003.

[6] AIAA Recommended Practice. 2003. Calibration of Subsonic and Transonic Wind Tunnels. AIAAR093-2003.

[7] AIAA Recommended Practice for Calibration and Use of Internal Strain-Gage Balances with Application to Wind Tunnel Testing, R-091-2003, AIAA Standards, 2003.

[8] Rašuo, B.: Scaling between Wind Tunnels-Results Accuracy in Two-Dimensional Testing, Transactions of the Japan Society for Aeronautical \& Space Sciences, Vol.55, No.2, March 2012., pp. 109-115.

[9] Ananda, G., K., Sukumar, P., P., Selig, M., S.: Measured aerodynamic characteristics of wings at low Reynolds numbers, Aerospace Science and Technology, Volume 42, April-May 2015, pp. 392-406

[10] Hemsch, M., Grubb, J., Krieger, W. Cler D.: 2000. Langley Wind Tunnel Data Quality Assurance: Check Standard Results. In: 21st AIAA Advanced Measurement Technology and Ground Testing Conference. AIAA 2000-2201.

[11] Ghorbanian, K., Soltani, M.,R., Manshadi, M., D., Experimental investigation on turbulence intensity reduction in subsonic wind tunnels, Aerospace Science and Technology, Volume 15, Issue 2, March 2011, pp. 137-147.

[12] Cummings, R.M., Morton, A., S., Siegel, G., S.: Numerical prediction and wind tunnel experiment for a pitching unmanned combat air vehicle, Aerospace Science and Technology, Volume 12, Issue 5, July 2008, pp. 355-364.

[13] Mundt, C., Boyce, R., Jacobs, P., Hannemann, K.: Validation study of numerical simulations by comparison to measurements in piston-driven shock-tunnels, Aerospace Science and Technology, Volume 11, Issues 2-3, March-April 2007, pp. 100-109.
[14] Ocokoljić, G., Damljanović D., Rašuo B. and Isaković, J.: 2014. Testing of a Standard Model in the VTI's Large-subsonic Wind-tunnel Facility to Establish Users' Confidence. FME Transactions. 42: pp. 212-218. doi:10.5937/fmet1403212O.

[15] Vuković, Đ. Samardžić, M., Marinkovski, D.: 2015. A simple upgrade of a balance calibration rig and its effect on the productivity, of a wind tunnel facility. In: 6th European Conference on Aeronautics and Space Sciences, EUCASS 2015.

[16] Stekenius K.A.: A method for determining angular and linear displacements of an aerodynamic model in a flow caused by deformation of its supporting devices // Cosmonautics and Space Technology. Korolev, TSNIIMash, 2000. № 22.

[17]AGARD. 1955. Specification for AGARD Wind Tunnel Calibration Models AGARD memorandum

[18] AGARD. 1958. Wind Tunnel Calibration Models. AGARD Specification 2.

[19] AIAA Guide to Nomenclature and Axis Systems for Aerodynamic Wind Tunnel Testing AIAA G129-2012, American Institute of Aeronautics and Astronautics 1801 Alexander Bell Drive, Reston, VA 20191

[20]Hills, R.: 1961. A review of measurements on AGARD Calibration Models, AGARDograph 64, Aircraft Research Association Bedford. England.

[21] Damljanovic, D., Vitic, A., Vukovic, Đ. Isaković, J.: 2006. Testing of AGARD-B calibration model in the T-38 Trisonic Wind Tunnel. Scientific Technical Review. 56 (2): pp. 52-62.

[22] Damljanovic, D., Isakovic, J. Rašuo, B.: 2013. T38 Wind-Tunnel Data Quality Assurance Based on Testing of a Standard Model. Journal of Aircraft. 50(4):pp. 1141-1149. doi:10.2514/1.C032081.

[23] Torregrosa, G., Fischer, B.: Rules for the design and manufacturing of wind tunnel models (2010). AQ/DRIM/PG/0401-4.0, ONERA, Paris.

[24] Ocokoljić G., Rašuo B., Kozić M.: Supporting system interference on aerodynamic characteristics of an aircraft model in a low-speed wind tunnel, Aerospace Science and Technology, Volume 64, Pages 133-146, (2017).

[25] Damljanović D., Rašuo B., Vuković Đ., Mandić S., Isaković J.: Hypervelocity ballistic reference models as experimental supersonic test cases, Aerospace Science and Technology, Volume 52, Pages 189-197, (2016).

[26] Galway, R.D. and Mokry, M.: 1977. Wind Tunnel Tests of ONERA Aircraft Models, National Aeronautical Establishment, Laboratory Technical Report, LTR-HA-5x5/0115, September 1977, Ottawa, Canada.

[27]Binion, t.W. Jr.: (1978) Tests of the ONERA Calibration Models in Three Transonic Wind Tunnels, Arnold Engineering Development, AEDC-TR-78-132.

[28] Yokokawa, Y., Aoki, Y., Morita, Y. et al.: (2005). Transition Measurements of the Aircraft-Model in the $6.5 \mathrm{~m} \times 5.5 \mathrm{~m}$ Low-Speed Wind Tunnel, In: Proceedings of the Wind Tunnel Technology Association $71^{\text {st }}$ Meeting, JAXA Special Publication. 
[29] Steinle, F. and Stanewsky, E.: 1982. Wind Tunnel Flow Quality and Data Accuracy Requirements. AGARD Advisory Rept. No. 184.

[30] Anderson, C.F.: 1970. An Investigation of the Aerodynamic Characteristics of the AGARD Model B for Mach Numbers from 0.2 to 1.0. Arnold Engineering Development Center. AEDCTR-70-100.

[31] Dijana B. Damljanović: Measurement accuracy of flow field parameters in supersonic wind tunnels, Doctoral Dissertation, Faculty of Mechanical Engineering, University of Belgrade, 2014.

[32] Goran J. Ocokoljić: Effect of the Guided Missiles Thrust Vector Control System Activity on Their Aerodynamics Characteristics, Doctoral Dissertation, Faculty of Mechanical Engineering, University of Belgrade, 2016.

\section{NOMENCLATURE}

$\begin{array}{ll}C_{A} & \text { axial force coefficient } \\ C_{N} & \text { normal force coefficient } \\ C_{m} & \text { pitching moment coefficient } \\ C_{D} & \text { total drag force coefficient } \\ C_{D f} & \text { forebody drag force coefficient } \\ C_{L} & \text { lift force coefficient } \\ C_{p b} & \text { base pressure coefficient } \\ L_{r e f} & \text { referent length of model, } \mathrm{m} \\ S_{r e f} & \text { referent area of model, } \mathrm{m}^{2} \\ M & \text { Mach number } \\ p_{s t} & \text { static pressure, bar } \\ p_{0} & \text { total pressure, bar } \\ q & \text { dynamic pressure, bar } \\ R e & \text { Reynolds number } \\ T_{0} & \text { total temperature, } \mathrm{K}\end{array}$

\section{Greek symbols}

$\begin{array}{ll}\alpha & \text { angle of attack, }{ }^{\circ} \\ \beta & \text { sideslip angle, }^{\circ} \\ \phi & \text { roll angle, }^{\circ}\end{array}$

\section{Acronyms}

F.S. Transducer full scale VTI Military Technical Institute
(Vojno-Tehnički Institut) Belgrade

AGARD Advisory Group for Aeronautical Research and Development

AEDC Arnold Engineering Development Complex - USA

NAE National Aeronautical Establishment

ONERA Office National d`Études et de Recherches Aeronautiques-Paris, France

\section{САВРЕМЕНИ ПРИСТУП МЕРЕЊА И \\ ПРОЦЕНА КВАЛИТЕТА СТРУЈАҢА У ПОДЗВУЧНОМ АЕРОТУНЕЛУ}

\section{Г. Оцокољић, Д. Дамљановић, Ђ. Вуковић, Б. Рawyo}

Захтеви за тачности мерења у аеротунелским тестовима постају све строжији, док се сложеност самог теста увећава. У условима смањеног расположивог времена за испитивање и повећања њихових трошкова, важно је да се у дужем временском периоду успоставе, спроводе и статистички контролишу прецизна баждарења и верификације свих елемената мерног ланца у аеротунелу. У раду су приказани напори, који су предузети за успостављање и одржавање система контроле квалитета мерења у подзвучном аеротунелу $T$-35 $4.4 m \times 3.2 \mathrm{~m}$, Војнотехничког института у Београду. Осигурање квалитета мерења у овом постројењу засновано је на осигурању квалитета баждарења радног дела, калибрације коришћење инструментације и периодичних испитивања стандардних аеротунских модела. Приказан је и узорак резултата релевантних калибрационих тестова, који је упоређен са резултатима из других аеротунела. Тестови су потврдили добар општи квалитет аеротунела. Постигнути ниво квалитета мора се стално одржавати, периодично проверавати и систематски документовати. 